Article

\title{
Parental Leave Reforms in Finland 1977-2019 from a Diversity Perspective
}

\author{
Anna Moring ${ }^{1}$ and Johanna Lammi-Taskula ${ }^{2, *}$ \\ ${ }^{1}$ Network of Family Diversity, 00500 Helsinki, Finland; E-Mail: anna.moring@monimuotoisetperheet.fi \\ ${ }^{2}$ Finnish Institute for Health and Welfare, 00271 Helsinki, Finland; E-Mail: johanna.lammi-taskula@thl.fi \\ * Corresponding author
}

Submitted: 30 October 2020 | Accepted: 5 February 2021 | Published: 11 June 2021

\begin{abstract}
In Finland, all parents, regardless of gender, are eligible for parental leave and there are no restrictive eligibility criteria. In practice, however, the statutory leave options are not equally available to all parents. Since the 1970s, steps have been taken in redesigning the leave scheme to make it more inclusive. Several reforms have been made to promote equality, mainly between women and men, but also between diverse families, such as adoptive families, multiple-birth families or same-sex parent families. The 'demotherisation' of parental-leave rights has slowly shifted the focus from biological mothers to fathers and non-biological parents. In the most recent reforms, the focus has widened from equality between parents to include equality between children regardless of the form of the family that they are born or adopted into.
\end{abstract}

\section{Keywords}

demotherisation; family diversity; gender equality; non-biological parents; parental leave; reform

\section{Issue}

This article is part of the issue "The Inclusiveness of Social Rights: The Case of Parental Leave Policies" edited by Sonja Blum (University of Hagen, Germany) and Ivana Dobrotić (University of Oxford, UK / University of Zagreb, Croatia).

(C) 2021 by the authors; licensee Cogitatio (Lisbon, Portugal). This article is licensed under a Creative Commons Attribution 4.0 International License (CC BY).

\section{Introduction}

Finland is a Nordic welfare state where national policies and public responsibility aim to support parents of young children in the reconciliation of paid employment and childcare responsibilities. Statutory maternity, paternity and parental leave schemes with earnings-related benefits cover the last month of pregnancy and almost one year after childbirth. After the parental leave period, parents can choose between publicly supported early childhood education services or care leave with a flat-rate child-home-care allowance paid until the child is three years old. Parents also have the right to a temporary care leave to take care of a child less than ten years of age who has fallen ill, as well as part-time leave to reduce working hours (Miettinen, Salmi, Närvi, \& Lammi-Taskula, 2020).

The eligibility for parental benefits is based on residence in the country, and leave rights are based on receiving the benefit. Finland is among the four EU Member States where there are no restrictive eligibili- ty criteria regarding, for example, employment or a heterosexual partnership (EIGE, 2020). In 2019, Finland also introduced equal paid parental leave for single mothers, giving them eligibility to the father's quota which was previously available only to single fathers and two-parent families. Finland could thus be seen as representing a universal parental leave model, where leave rights are inclusive for all parents. However, Dobrotić and Blum (2019) place Finland as a borderline case between the universal model and the selective mixed model, where some parents are excluded from the schemes. Even if the formal eligibility for leave is universal, in practice the statutory leave options are still not equally available to all parents.

During the past decades, several parental leave reforms have been made to promote equality in leave possibilities and take-up. The focus has mainly been on gender equality, i.e., the weaker position of women in the labour market and the more marginal position of men as parents (Hiilamo \& Kangas, 2009; Lammi-Taskula, 2007; Sipilä, Repo, \& Rissanen, 2010). The main tool 
for promoting gender equality has been the father's leave quota that cannot be transferred to the mother. The non-transferable father's quota has resulted in higher take-up of leave by fathers (Duvander et al., 2019; Salmi \& Lammi-Taskula, 2015). This development can be called 'demotherisation' (Mathieu, 2016), referring to the degree of independence mothers enjoy from the necessity of performing care work, and the extent to which they can offload childcare responsibilities onto other caregivers.

However, socio-economic inequalities produce variation in the conditions and consequences of leave take-up and sharing (Duvander \& Johansson, 2016). For example, mothers with a lower education level and more precarious position in the labour market take longer leave periods with a relatively low benefit level, which is often detrimental to their labour market position as well as the socio-economic conditions of their children. The father's quota has been used more by two-parent families with higher socioeconomic status while those in more precarious positions have not been able to use it (Haataja, 2005; Lammi-Taskula, 2004; Salmi \& Närvi, 2017).

In this article, we analyse parental leave reforms in Finland from the perspective of demotherisation (Mathieu, 2016) and inclusion of diverse families, i.e., families that differ structurally from a nuclear family form. We ask how the process of social inclusion has proceeded concerning the simultaneous process of demotherisation, and whether and how these two processes are interdependent. We show that the demotherisation process of parental leave in Finland from the early 1970 s onwards has not only driven the system of parental leave schemes from supporting mainly biological mothers toward supporting biological fathers but also increased the parental leave eligibility and social inclusion of non-biological parents. We ask what the relationship is between promoting more active participation of fathers in childcare and the diversification of the parental leave eligibility. Based on our analysis of the Finnish leave policy development, we argue that what Sophie Mathieu (2016) has described as the demotherisation process has been a process of shifting the care responsibilities of the biological mother toward whomever else is there to care for the child, and that this form of biological demotherisation has been crucial for making the parental leave system more inclusive for parents and children living in diverse family forms.

We start with a conceptual part, defining our use of the concepts of family diversity and demotherisation. Then we introduce a brief history of parental leave reforms in Finland from a diversity perspective. Since the 1960s, several reforms have been introduced, usually designed in tripartite working groups with representatives from the central employers' and employee's unions and the state (Lammi-Taskula \& Takala, 2009). Finally, we focus on the two most recent leave reform proposals, one proposed in 2016 (failed in 2018), and another proposed in 2019 (presently in process). We show that the progress towards more social inclusion has been gradual and slow, and many aims and proposals to broaden eligibility have re-entered the negotiations again and again. We claim that the shift towards promoting fathercare, and simultaneous demotherisation, has paved the way to parental leave eligibility of non-biological parents and parents in diverse family situations.

\section{Family Diversity and Demotherisation}

In family research, a wide variety of meanings have been given to the concept of family diversity, including non-traditional families such as reconstituted families, adoptive families, single-parent families, and same-sex parent families as well as families belonging to ethnic or racial minorities, and addressing different parenting styles (Cygan-Rehm, Kuehnle, \& Riphahn, 2018; Fine, 1993; Jou, Wong, Franken, Raub, \& Heymann, 2020; Picken \& Janta, 2019; Wong, Jou, Raub, \& Heymann, 2019). In the context of parental leave policies, we use the concept to refer to families that differ structurally from the traditional nuclear family form. Specifically, we have looked at parental leave eligibility of single-parent families, stepfamilies, adoptive families, multiple-birth families, same-sex parent families, families who have lost a child, and foster families.

In Finland, family diversity has been recognised stepwise in parental leave reforms since the 1970s, starting with adoptive families and advancing to multiple birth families in the 1980s and same-sex parent families in the 2000s. The next section will give an outline of the development in more detail.

Parallel to the concept of family diversity, we use the concept of demotherisation presented by Mathieu (2016), defined as to which extent mothers can transfer part of their caregiving responsibilities to the state, grandparents, their partner or paid caregivers. Mathieu presents four types of maternalism promoted by social policies: implicit maternalism, state-funded dematernalism, traditional maternalism and familialised dematernalism. We locate the Finnish case to the borderline of state-funded dematernalism, where care work is shifted from the family unit to state-funded care institutions, and implicit maternalism, where mothers (sometimes referred to in gender-neutral terms as caregivers, as Mathieu points out) are offered time or money to look after dependents (Mathieu, 2016, pp. 582-583). On the one hand, the dualistic Finnish childcare policy (Sipilä et al., 2010) includes a subjective right for children to early childhood education and care after parental leave, but on the other hand, a flat-rate cash-for-care benefit is offered for a parent or other caregiver to stay at home until the child is three years old.

Evertsson, Jaspers, and Moberg (2020) use the concept of 'parentalisation' to refer to the legal and policy changes that make parenthood possible for parents in same-sex families. In their account of same-sex parents' eligibility for parental leave in five Nordic countries, they 
name leave rights as crucial factors for parentalisation. Leave reforms that broaden the scope of parental leave eligibility can be seen as significant in the parentalisation of also other de-facto parents living in diverse families, for example, step-parents, or parents in foster families.

As we shall show, in the development of the Finnish parental leave scheme, demotherisation and the inclusion of diverse family forms are simultaneous processes that are entwined, but not always unilateral. The dimension of socio-economic equality is also at play (Cygan-Rehm et al., 2018; Kaufman, 2018). In the Finnish context, while the majority of parental leave days are gender-neutral and both parents are eligible to use them, mothers still use the vast majority of all parental leave days (Miettinen \& Saarikallio-Torp, 2020). There is, however, a clear socioeconomic division in leave take-up among families, especially mothers. Those with a high education level and a more secure position in the labour market return to paid employment earlier with the help of early childhood education and care services, whereas those with a more precarious position use longer periods of the low cash-for-care benefit (Lammi-Taskula, 2004; Miettinen et al., 2020; Salmi \& Närvi, 2017).

For the purpose of this study, we have systematically gone through the parental leave reforms in Finland from 1963 to the present day, both government proposals and actual legislation. We analyse this data through the concepts of demotherisation and family diversity in parental leave eligibility and scrutinise the tendencies at play in the development of these reforms.

\section{Data and Analysis Method}

The data in this section consist of revisions made to the Act of Health Insurance (The Finnish Government, 1963) concerning paid parental leave in Finland from 1963 until the end of 2020, reports of government task forces considering parental leave in 2005-2017, government proposals related to parental leave reforms of 2017 and 2019, and background material consisting of proposals of parental leave models by researchers, labour market organisations and other stakeholder organisations, as well as material from the on-going parental leave reform published by the Ministry of Social Affairs and Health.

The revisions of the Act of Health Insurance are analysed to highlight the order, timeline and substance of changes that have been put into practice. The task force reports, government proposals and background material have been chosen as complementary data to analyse the debate related to the preparation of legal changes. Through this combination of data, we can grasp the logic behind the parental leave reforms, the competing political and stakeholder interests and the resulting practical policy measures.

Data of the legal revisions were gathered from the Finlex database (www.finlex.fi), which contains all acts of the Finnish legislation, previous versions of the acts and a history of revisions made to each specific act. Data of the task forces and background data of the on-going reform were gathered from the website of the Ministry of Social Affairs and Health. The task force reports were limited to the period of 2005-2017 when the discussion of family diversity became more central. After 2017, parental leave reforms were prepared without official task forces, so the background analysis is based on the government proposals on reforming the Act of Health Insurance.

The data were systematically gathered from the abovementioned sources, and analysed through qualitative content analysis, complemented with close reading, the concepts of family diversity and demotherisation as starting points (Herrnstein Smith, 2016; Schreier, Stamann, Janssen, Dahl, \& Whittal, 2019). Qualitative content analysis is suitable for analysing conceivable amounts of specifically chosen data, whereas a close reading of selected documents, identified as significant, provides for a more detailed qualitative examination of the content, argumentation, and purpose of these documents.

The reforms to the Act of Health Insurance were first read through to select those that included changes in parental leave, looking for the specific paragraphs to which the changes were directed. The reforms that had to do with maternity, paternity or parental leave were then further analysed to see whether they were related to family diversity, as defined in the context of this article. The reforms containing this kind of substance were then sequenced by year and content, as presented in Table 1, and subjected to close reading. The task force reports, and government proposals, identified as crucial complementary data, were closely read from the perspective of family diversity and demotherisation. In the following sections, the data will be reported in chronological order, with an analytical focus on the more recent discussions from the perspective of the concept of demotherisation.

\section{Findings}

\subsection{Early Family Leave Reforms in Finland from a Diversity Perspective}

The first modern form of parental leave in Finland was directed to biological mothers as maternity leave was legislated in 1963. Maternity leave was nine weeks, one-third of which was to be taken before the due date and two-thirds after (364/1963). Maternity leave was gradually increased in 1977 to 7.5 months and further to 10.5 months in 1981.

Fathers got the right to two weeks of paternity leave in 1977 (The Finnish Government, 1977, 1981). From 1981 to 1985, married fathers had the right to use the last four months of maternity leave with the mother's permission. In 1985, parental leave that could be shared between the mother and the father was introduced, and eligibility was extended to unmarried fathers cohabiting with the mother and the child (The Finnish Government, 1985). 
The first step towards broader eligibility among diverse families was made in the late 1970s, when parents of adopted children were given the right to parental leave in 1977 (1086/1977; see Table 1). Mothers of adopted children could take maternity leave up to 6.5 months from the birth of the child, or at least three months if the child was not a new-born when adopted. In 1981 this was increased to match the leave right of biological mothers, and the leave period was extended to 9.4 months from the birth of the child, or at least four months with older children (471/1981). The 1981 reform also included the possibility for adoptive fathers to use up to four months of maternity leave with the mother's consent.

Leave eligibility related to the death of a child or parent was reformed in the 1980s. In 1981, mothers to stillborn children were given the right to take four months of maternity leave (The Finnish Government, 1981) and five years later fathers to stillborn children got the right to two weeks of paternity leave (The Finnish Government, 1986a). In 1985, fathers were explicitly given the right to take over the remaining period of maternity leave in case of death of the mother (The Finnish Government, 1985). If the father did not take care of the child after the mother's death, the leave could be granted to another person who took care of the child.

Soon after introducing gender-neutral parental leave, non-citizens were also included in the universal parental leave scheme. Parents who were not Finnish citizens but had been residing in Finland for more than 180 days were given the right to parental leave in 1986 (The Finnish Government, 1986b).

In 1994, a mother of a child taken into custody lost the right to parental leave during the time the child was not in her care (The Finnish Government, 1994). At the same time, the right to parental leave was extended to a father who did not live with the mother of the child but took care of the child, on the condition that the mother was not involved in caring for the child. This change strengthened the ethos that both parents are responsible for the child-if one is unable, then the other can take over.
The leave rights of multiple birth families were extended in the 1990s. They got a 2.5-month increase in parental leave in 1992 (The Finnish Government, 1992). Four years later, this increase was multiplied by the number of children born simultaneously (The Finnish Government, 1996), giving families with triplets, quadruplets etc. an even longer leave period. The need for both parents to stay at home together was recognised in 2002 as multiple birth families got the right to use the prolonged parental leave days simultaneously with the other parent's leave (The Finnish Government, 2002a).

A four-week father's quota for two-parent families where the parents lived together was introduced in 2003 (The Finnish Government, 2002b) and lengthened in 2010 by two weeks (The Finnish Government, 2009). In 2013, the father's quota and the 'old' paternity leave were merged into a nine-week paternity leave, of which three weeks can be taken simultaneously with the mother. The 'new' paternity leave can now be used until the child is two years old.

From a family diversity perspective, the lengthening of the father's quota was inadvertently increasing the inequality of single-mother families (Cygan-Rehm et al., 2018; Jou et al., 2020). Specifically, the increase of the father's quota that could be used after the maternity leave and parental leave periods would increase the length of paid parental leave only for two-parent families but not for single-mother families. Single fathers, however, were able to use the father's quota as well as the parental leave days.

Same-sex couples got the right to share parental leave in 2007 (The Finnish Government, 2006). In 2010, following the right to second-parent adoption of the partner's juridical child, the same-sex partner of a birth mother got the right to three weeks of paternity leave concerning the birth/adoption of the child (The Finnish Government, 2010). It was not until 2018, however, that same-sex unmarried cohabiting partners could share parental leave equally with their different-sex peers (The Finnish Government, 2016).

The development from the 1960s to the 2000s brings to light a demotherisation tendency of distancing

Table 1. Amendments of parental leave for diverse families in Finland, 1977-2019.

\begin{tabular}{ll}
\hline 1997 & Adoptive mothers gained the right to parental leave (1086/1977) \\
1981 & Mother of a stillborn child gained the right to parental leave $(471 / 1981)$ \\
1985 & Unmarried fathers gained the right to share parental leave with the mother $(32 / 1985)$ \\
1985 & Parental leave possible for citizens of other countries than Finland based on residence in Finland (32/1985) \\
1986 & Father of a stillborn child gained the right to parental leave (458/1986) \\
1992 & Parents of multiple birth children gained a 60-day extension of parental leave $(1653 / 1992)$ \\
1994 & Mother whose child taken into custody no longer eligible for parental leave $(1501 / 1994)$ \\
1994 & Father who does not reside with mother eligible for parental leave (1501/1994) \\
2002 & First individual quota for fathers (1075/2002) \\
$2002-2019$ & As the quota for the father increases, single mothers have less leave than two-parent families
\end{tabular}


parental leave eligibility from what we call the hegemony of the birth mother. This development starts from the introduction of paternity leave in 1977 and continues through the inclusion of adoptive parents to removing the right of the birth mother to parental leave in case she is not involved in the care of the child. Simultaneously, the eligibility of fathers in different family formations to parental leave has been increased by giving non-resident or divorced fathers the right to leave, and fathers in multiple birth families the right to take parental leave simultaneously with the mother. Fathers have also been given a leave quota that cannot be transferred to the mother.

The leave rights of diverse families have been increased step by step, creating more social inclusion. However, from the perspective of gender equality, these reforms have not been radically successful. Although we see an increase in the number of parental leave days taken by the fathers, a majority of the gender-neutral parental leave that can be used by both parents is still taken by mothers (Miettinen \& Saarikallio-Torp, 2020). Thus, the process of demotherisation, while impressive on paper, remains quite unimpressive in practice.

\subsection{Foregrounding Family Diversity}

The needs of diverse families have been addressed in several parental leave reforms since the early 1980s. However, the progress has been slow and gradual, and at the turn of the century, the leave rights were still far from equal. A systematic review of the whole parental leave scheme from a family diversity perspective was missing, and policy recommendations and proposals to change legislation would be only partial. During 2005-2017, several task forces were appointed to make proposals for a more inclusive leave scheme (for reports of the work of these task forces see, for example, STM, 2005, 2011, 2015a, 2017a, 2017b, 2017c).

In 2005, two Government reports on leave reforms were published, one containing proposals for achieving more effective equalisation of the leave costs between employers in female and male-dominated branches (STM, 2005), and the other proposing reforms of parental leave from the users' point of view (Työministeriö, 2005). The proposals for equalising leave costs included full salary compensation during the first months of the maternity leave in all branches as well as increasing the amount of parental benefit paid to the employer in case the parent receives full salary during leave, and compensation for the time spent caring for a sick child.

The proposals related to different groups of leave users included greater flexibility in the timing of the father's leave quota so that fathers could postpone their leave until the end of the mother's care leave or vacation. It was also proposed that parents (mostly fathers) who live apart from their child and have joint custody would have the right to temporary childcare leave to look after a sick child and that the rights of adoptive parents should be improved by increasing their parental leave right to eight months and home care leave to two years, starting from when the child is placed in their care (Työministeriö, 2005). Furthermore, it was proposed that parental leave allowance would be payable also to a registered same-sex partner (Salmi \& Lammi-Taskula, 2005; Työministeriö, 2005).

The social partners and political parties were quite unanimous on these proposals and most of them were soon actualised. Since 2006, a parent who does not live with the child but has joint custody is also entitled to temporary childcare leave to care for a sick child less than 10 years of age. In 2007, the percentage of earnings replaced by leave benefits was raised from $70 \%$ to $75 \%$ for the first 35 days of parental leave, and the parental leave period for adoptive parents was lengthened from 7.2 months to eight months (The Finnish Government, 2006). Same-sex parents in a registered relationship were given the right to share parental leave. Adoptive parents became entitled to home-care allowance (as an alternative to public day care) also for a child older than three years (Salmi \& Lammi-Taskula, 2009; The Finnish Government, 2006).

These changes did improve the leave possibilities of other carers than birth mothers, but still, the big picture of childcare practice remained gendered, heavily leaning toward birth mothers. As a reaction to the slow process toward more gender equality, a leave model with significantly longer father's quotas (the $6+6+6$ model; six-month quotas for each parent, and six months of sharable leave) was presented in 2006 by researchers (Salmi \& Lammi-Taskula, 2010). This model was soon adopted as a goal by the Council for Equality, the Green Party and the Left Alliance, and the Finnish Confederation of Salaried Employees. The model also faced criticism for being on the one hand too radical, and on the other hand not addressing family diversity-such as same-sex parents, single mothers, and stepfamilies.

In 2014, the Minister of Social Affairs and Health set up a task force to consider the situation of diverse families concerning parental leave legislation. This was the first comprehensive attempt in Finland to grasp the complexities of parental leave for diverse families. The task force consisted of representatives of NGOs specialising in diverse families, including LGBTIQ+ families, multiple birth families, adoptive families, single-parent families, as well as a representative from the Network of Family Diversity.

The task force report (STM, 2015a) included several proposals on how to change the parental leave legislation towards the greater inclusion of different family situations. These included, but were not limited to, giving same-sex unmarried parents the right to parental leave; extending the parental leave of single mothers to the same length as that of single fathers; giving multiple birth fathers three weeks of parental leave for each child born simultaneously; extending the leave right of single fathers who take care of the child, but do not reside with 
the birth mother, to equal the length of maternity leave; and extending the parental leave of adoptive parents to match that of birth parents.

The systematic analysis of the leave scheme by the working group revealed that the system originally built on the logic of primacy of the birth mother was still based on an assumption that biological, legal, and actual parenthood coincide. The conclusion was that a large-scale parental leave reform was needed, built on a presumption of family diversity (STM, 2015b).

The timing of these different processes-the demotherisation of parental leave and the systematic attempt to include family diversity-indicates that the two are simultaneous and interdependent on an ideological level, but not necessarily intertwined on a practical level. We find that the demotherisation of leave rights is a precondition for the inclusion of diverse families, opening up space for non-biological and social parents even if the change of practice is slow. Thus, the outspoken ideal of equality, even if it takes the form of Mathieu's (2016) model of implicit maternalism, where mostly mothers take paid leave to take care of dependents, opens up for a diversification of the parental leave scheme. The slow crumbling of the hegemony of the birth mother shows in the increase of the father's quotas, but also in legal changes such as declining parental leave if the child is taken into custody or giving parental leave to adoptive parents. But further demotherisation was still needed to enhance the process of increasing family diversity.

\subsection{Diversity and Demotherisation at Work: From 2016 to the Present Day}

Unlike several previous governments, the conservative coalition government appointed in 2015 did not include a parental leave reform in its program (Elomäki, Mustosmäki, \& Koskinen Sandberg, 2020). As a reaction, a lively public debate started, and many different leave models were suggested by various interest groups.

In 2016, inspired by the diversity workgroup from 2015, the Central Organisation of Finnish Trade Unions (SAK, 2016) presented a parental leave model, followed soon by other labour market organisations and most political parties (Heinonen \& Saarikallio-Torp, 2017; Keskusta, 2016; Kokoomus, 2017; Oksala, 2017; Social Democratic Party, 2017; Vihreät, 2016). The common feature in most models was a longer quota for fathers, and reductions of the home care allowance (Salmi, 2017). The majority of these models were also inclusive of a wide range of diverse family forms.

Pressured by the public debate, the government started a parental leave reform in the autumn of 2017 (resulting in the 2018 amendment; see The Finnish Government, 2018), aiming at increasing both gender equality and equality between children living in diverse families. Earlier that year, fathers who did not live with the mother of their child were given eligibility for paternity leave (Miettinen \& Saarikallio-Torp, 2020), as they were already eligible for temporary leave to care for a sick child and the administrative interpretation was adjusted to cover paternity leave with a similar logic.

The preconditions set by the government for the reform were strict and to some extent contradictory: The reform should be child and family-oriented, it should increase gender equality in work and family, the possibility to home care until the child is three years old should be kept intact, and public spending should not increase (STM, 2017a). The reform was framed as an employment policy reform, thus the labour market perspective was dominant while questions of care were not discussed much (Elomäki et al., 2020).

The contradictions in the preconditions are interesting from the demotherisation perspective. As we claimed earlier, Finland's dualistic family policy is, in terms of Mathieu's concepts, a mix of implicit maternalism and state-funded demotherisation. On the one hand, the explicit requirement for the reform was 'child and family orientation' together with taking family diversity and gender equality into account, in practice allowing for more paid parental leave for all two-parent families by lengthening the father's quota (also same-sex partners of the birth mother can use this quota). On the other hand, the reform was required to preserve the cash-forcare allowance until the child is three years of age. This benefit is used mainly by mothers (Miettinen et al., 2020) so, in practice, demotherisation was compromised with this restriction of the reform.

From the models presented by various political parties and organisations, two models were on the table in the final stage, both aiming at a longer, non-transferable father's quota and a shorter transferable leave period (STM, 2017c). Against the requirements, both models also included a considerable cut to the cash-for-care allowance. Preparations for the reform were broken off after six months in February 2018, based on calculations by the Ministry of Finance showing that there would be only a small increase in the employment rate for mothers, while the financial consequences would be hardest on families in a weaker socio-economic position (Salmi, Närvi, \& Lammi-Taskula, 2018).

Despite the failure of the efforts to promote gender equality with a longer father's quota, preparations related to equality between children in diverse families continued. The government lengthened the parental benefit period for adoptive parents, multiple birth families and single mothers (Salmi et al., 2018; The Finnish Government, 2018). These changes were largely based on the proposals made by the Ministry of Social Affairs family diversity workgroup in 2015 (STM, 2015a). The main changes included giving single mothers the right to use the father's quota and thus get the same amount of leave as two-parent heterosexual families, giving multiple birth fathers three weeks of leave for each child born at the same time, and extending the parental leave for adoptive parents to match the leave of families with biological children. 
These changes fixed some of the most acute inequalities related to the leave rights of diverse families, while many issues remained. It is evident, however, that in this specific political environment, with a conservative coalition in power, demotherisation did not prevail but family diversity did. The proposed restrictions to child home care failed, leaving Finland stuck in the apparently gender-neutral system that in practice adheres to Mathieu's concept of implicit maternalism. However, the measures to increase the social inclusion of diverse families were implemented as a partial reform of the existing policy, making the parental leave scheme more equal for single-parent, adoptive, multiple birth, same-sex and stepfamilies.

The progressive pro-gender equality tendencies were not completely thwarted and will get a new chance in the on-going parental leave reform. Next, we focus briefly on the prospects of parental leave rights through an account of a structural parental leave reform that is currently being prepared in Finland, involving radical demotherisation as well as the inclusion of family diversity on an even larger scale.

To address the gender equality challenges, the 2019 parental leave reform proposal includes a radical rethinking of gender neutrality toward a $1+7+7$ system of parental leave, which would give both parents in a two-parent family equal shares of leave, part of which could then be transferred to the other parent (STM, 2020). This indicates that the goal is radical demotherisation, with an insistence on the inclusion of family diversity, as we shall proceed to show.

In 2019, a coalition government (Social Democrats, Centre Party, the Greens, the Left Alliance and the Swedish People's Party) included a parental leave reform in its program. The aim was to promote a more equal division of labour in childcare between parents as well as equality between children living in diverse families. The gender-specific names of leave periods (maternity leave, paternity leave) were changed into gender-neutral ones. Instead of 'mothers,' the proposal talks about 'pregnant parents' and instead of 'fathers,' 'other parents' are addressed (STM, 2020).

In the coming reform, the government wants to extend the earnings-related parental benefit period and divide it symmetrically so that each parent gets 6.4 months of leave. Single parents would have a right to both quotas. In families with two parents, each parent could transfer 2.5 months to the other parent. Thus, the non-transferable quota for each parent would be 3.9 months. This transfer could also be made to the spouse of the parent, thus including stepfamilies and same-sex parent families with more than two de-facto parents. The pregnant parent would be entitled to up to five weeks of leave before the birth of the child (STM, 2020). The reform would not include any changes in the homecare allowance. An unofficial tripartite group was called to support the Ministry of Social Affairs and Health in preparing the reform (Miettinen et al., 2020).
With the gender-neutral terminology, the eligibility for parental leave would be the same for all legal parents, biological or non-biological and irrespective of gender. Thus, the focus is on the right of any child to be cared for by their parents. One of the premises of the reform is the inclusiveness of diverse families. There are, however, very little concrete facts available yet on what this means in practice.

\section{Discussion}

The focus of this article has been on the changes of the Finnish parental leave scheme from the perspectives of family diversity and demotherisation. Following the classification of Dobrotić and Blum (2019) that questions the Finnish parental leave scheme as a universal model, we have noted that not all parents have been equally eligible for parental leave during the past decades. However, Finland has advanced from a leave policy based on the hegemony of the birth mother towards a regime of explicit parental equality, and the equality of children regardless of their family form.

It is noteworthy that the starting point of the ongoing reform is quite different from previous reforms. In the face of the hegemony of the birth mother, this reform promotes equality, at least formally, as it emphasises the inclusion of non-biological and/or non-resident parents. The reform also addresses gender-neutrality, which Mathieu (2016) says is indicative of the implicit maternity model of social policy, as it explicitly gives the other parent-in two-parent heterosexual nuclear families, the father-half of the leave. As the main perspective is that of the child, the reform aims at the equality of all children regardless of the family form in addition to increased gender equality in working life and family life.

Regardless of whether or not the reform will be passed, the proposed model is a step in a new direction that is not radically divergent from previous debates but does attempt a radical leap away from an institutionally reproduced hegemony of the birth mother. Thus, the ongoing reform would move Finland toward what Dobrotic and Blum (2019) call a universal adult-worker model of parental leave policy. It is more difficult to determine what the new regime would mean in Mathieu's terms. It would still not be completely state-funded dematernalisation, but clearly a step away from implicit maternalism, toward something that could be classified as familialised dematernalism-a situation where other family members take more responsibility for care voluntarily. However, in Mathieu's conception, in familialised dematernalism care work occurs through kin solidarity or father's involvement but is not financed by taxpayers (Mathieu, 2016, p. 583). In the on-going Finnish reform, the policy measures of implicit maternalism are partly intact in the form of cash-for-care, while an explicit increase of parental leave days to the other parent (father) is made. Thus, this system would fall outside the four-concept model that Mathieu suggests. We might 
refer to this as a model of explicit (parental) equalityone that contains the ideals of demotherisation and simultaneous familialisation while being state-funded and including a strong financial incentive for families to use both parents' parental leave quotas.

The ideal of equality in the proposed new model is not, however, limited to equality between parents. A significant element of the model is equality between children regardless of family form. In practice, this means positive discrimination of some parents, such as single parents of all genders, who would be eligible for longer parental leave than two-parent family parents have in case the other parent does not use their quota.

These two tendencies-demotherisation and inclusion of family diversity-have been present throughout the modern history of Finnish family leave reforms. Step by step, the hegemony of the birth mother has been deconstructed on the symbolic level of policies. In practice, however, it has still prevailed in the actual take-up of parental leave. This indicates that formal gender neutrality and formal equity do not necessarily lead to equality in practice (Mathieu, 2016). Simultaneously, we find that the deconstruction of the hegemony of the birth mother, while only on the level of formal equity, is a necessary precondition of the increased social inclusion of diverse families-an aspect that has not been addressed much in previous research on parental leave policies.

The hegemony of the birth mother was visible as a starting point when the first modern parental leave regimes were installed in the early 1960s. Several reforms have created gradual progress of distancing from this hegemony, which can be seen as a demotherisation process of parental leave. This progress took place through two different strands of development: the explicit increase of father's rights and responsibilities and making parental leave and benefits available to a wider range of diverse parenthood.

The main question in this tale of slow progress centres on the role of the birth mother. On the one hand, the physical needs of the birth mother, in the future to be known in the Finnish terminology as the birth giver, need to be met through securing a specific pregnancy-related leave period. At the moment, a four-month pregnancyrelated leave is guaranteed to all birth givers whose pregnancy has lasted for more than 154 days, regardless of whether the child is given up for adoption, is being raised by its father(s), is taken into custody from birth or even dies at birth or is stillborn.

On the other hand, after this recovery period, the rest of the parental leave can be shared with the other parent-the father or the birth giver's spouse. This freedom of choice in itself marks a distancing from the hegemony of the birth mother-a movement from protecting the relationship of the child and the mother toward a more inclusive understanding of the family of the child. In terms of Mathieu's theory, this could be understood as a move toward greater demotherisation while still acknowledging the health needs of the birth giver after childbirth. The birth giver is protected as a person whose physical wellbeing requires a period of rest after giving birth, but the focus of the parental leave system has turned toward the child and the right of the child to be cared for, as well as securing enough time for the child together with both parents.

It has been noted throughout this analysis that despite a long history of parental leave reforms questioning the hegemony of the birth mother, most parental leave is still used by them. As the father's quota has been made longer and more flexible, more fathers have used it. There are, however, clear socio-economic differences in the take-up, and a relatively large group of fathers do not use their quota. Inequalities between families may have grown, as mainly those with a higher education level and a better position in working life have used the possibility to share leave (Miettinen \& Saarikallio-Torp, 2020). These inequalities are important to consider in further analyses of parental leave regimes, to understand the expected implications of different models. As Cygan-Rehm et al. (2018) point out in a German context, and Kaufman (2018) in a British one, a parental leave reform may be very effective for those who benefit from it, but careful consideration is in place to identify the situations where the reform is of minimal or no benefit-for example for families outside the labour market, or in situations where the statutory pay is not sufficient to cover for the salary loss during the parental leave.

The most recent changes in the leave scheme in Finland have focused on broadening the eligibility to parental leave and benefits to cover more than just the presumed two parents - the birth mother and the genetic father. This has been disrupting the logic of biologi$\mathrm{cal} /$ genetic parenthood and foregrounding the social and psychological dimensions of parenthood. There is a will to make parental leave available to those who actually take care of the child, regardless of their biological or legal bonds to the child or its birth giver. This is a form of familialised dematernalism in Mathieu's terms, but the system less vulnerable and less dependent on voluntary care work as the Finnish parental leave system is based on tax-funded salary compensations.

We suggest that the more systematic discussion around diversity marked a turning point in the discourse on parental leave in Finland. After 2015, the focus was turned from a gradual increase in fathers' leave periods, and slight modifications to include diverse family situations, toward a larger-scale structural reform of the parental leave scheme. This change is marked by a shift of focus from the perspectives of the parents-which parent gets how much leave-to the perspective of the child. The increased inclusion in parental leave can also be seen to lead to broader parentalisation (Evertsson et al., 2020) in diverse families, and thus to the increased ability of families to share care work and responsibilities.

In the on-going reform, one of the aims is to secure the right of every child to an equal amount of time being cared for at home, regardless of the family type the child 
is born or adopted into. Less weight is put on whether the person caring for the child is the mother, father or someone else. Based on our analysis, we claim that an analysis of social policies concerning demotherisation will benefit from a simultaneous analysis focusing on family diversity in a broad sense. Both of these processes are dependent on how strong an emphasis there is on the hegemony of the birth mother, and both are based on an explicit claim for equality-between parents of all genders, and between children regardless of family form.

\section{Acknowledgments}

The authors are grateful to the editors of this journal and the anonymous referees, whose comments on earlier versions of the article have been very valuable and have enabled us to profoundly improve the manuscript. Furthermore, we thank the International Network on Leave Policies and Research for the annual reports of leave policy development, and the members of the Network of Family Diversity in Finland for their insights on leave reforms. We would also like to thank MA Milka Nissinen for her help with the English language.

\section{Conflict of Interests}

The authors declare no conflict of interests.

\section{References}

Cygan-Rehm, K., Kuehnle, D., \& Riphahn, R. T. (2018). Paid parental leave and families' living arrangements. Labour Economics, 53, 182-197.

Dobrotić, I., \& Blum, S. (2019). Inclusiveness of parentalleave benefits in twenty-one European countries: Measuring social and gender inequalities in leave eligibility. Social Politics: International Studies in Gender, State \& Society, 27(1), 588-614.

Duvander, A., \& Johansson, M. (2016). Parental leave use for different fathers: A study of the impact of three Swedish parental leave reforms. In G. Eydal \& T. Rostgaard (Eds.), Fatherhood in the Nordic welfare states. Comparing care policies and practice (pp. 349-374). Bristol: Policy Press.

Duvander, A., Eydal, G., Brandth, B., Gislason, I., LammiTaskula, J., \& Rostgaard, T. (2019). Gender equality: Parental leave design and evaluating its effects on fathers' participation. In P. Moss, A. Duvander, \& A. Koslowski (Eds.), Parental leave and beyond. Recent international developments, current issues and future directions (pp. 187-204). Bristol: Policy Press.

EIGE. (2020). Eligibility for parental leave in the EU member states. Luxembourg: Luxembourg Publications Office of the European Union.

Elomäki, A., Mustosmäki, A., \& Koskinen Sandberg, P. (2020). Kamppailuja merkityksistä, kustannuksista ja vaikutusvallasta-Juha Sipilän hallituksen perhe- vapaauudistuksen kaatuminen kolmikantaisen tasaarvopolitiikan näkökulmasta [Struggles of meanings, costs and power: The falling of the parental leave reform of Juha Sipilä Government from the perspective of tripartite gender equality policy]. Politiikka, 62(1), 33-55. https://doi.org/10.37452/politiikka. 88407

Evertsson, M., Jaspers, E., \& Moberg, Y. (2020). Parentalization of same-sex couples: Family formation and leave rights in five Northern European countries. In R. Nieuwenhuis \& W. Van Lancke (Eds.), The Palgrave handbook of family policy (pp. 397-422). Cham: Palgrave Macmillan.

Fine, M. A. (1993). Current approaches to understanding family diversity. Family Relations, 42, 235-237.

Haataja, A. (2005). Äidit ja isät työmarkkinoilla 19892002/2003 [Mothers and Fathers on the Labour Market 1989-2002/2003]. Social and Health Ministry Proceedings, 29. Retrieved from https://julkaisut. valtioneuvosto.fi/handle/10024/72413

Heinonen, H., \& Saarikallio-Torp, M. (2017). Perhevapaamallit äitien puntarissa [Mothers' opinions on parental leave models]. Kela Research Blog. Retrieved from https://tutkimusblogi.kela.fi/arkisto/ 3854

Herrnstein Smith, B. (2016). What was 'close reading'? A century of method in literary studies. Minnesota Review, 87, 57-75.

Hiilamo, H., \& Kangas, O. (2009). Trap for women or freedom to choose? The struggle over cash for child care schemes in Finland and Sweden. Journal of Social Policy, 38, 457-475. https://doi.org/10.1017/ S0047279409003067

Jou, J., Wong, E., Franken, D. Raub, A., \& Heymann, J. (2020). Paid parental leave policies for single-parent households: An examination of legislative approaches in 34 OECD countries. Community, Work \& Family, 23(2), 184-200. https://doi.org/10.1080/13668803. 2018.1517083

Kaufman, G. (2018). Barriers to equality: Why British fathers do not use parental leave. Community, Work \& Family, 21(3), 310-325.

Keskusta. (2016). Keskustan perhepaketti. Keskustan tavoitteet perhevapaajärjestelmän uudistamiseksi. [Center Party's family package. Goals for parental leave reform]. Keskusta. Retrieved from http://huolenpitoa.fi/loader.aspx?id=4f7b79ae2cb1-49e1-bb91-5d7670f6951b

Kokoomus. (2017). Kokoomuksen perheet ja työelämä [National Coalition Party's view on families and working life]. National Coalition Party. Retrieved from https://www.kokoomus.fi/kokoomus-julkaisiperheet-ja-tyoelama-asiakirjan

Lammi-Taskula, J. (2004). Äidit työmarkkinoilla-Kahden kerroksen väkeä? [Mothers on the labour marketTwo class people?]. Yhteiskuntapolitiikka, 69(2), 202-206.

Lammi-Taskula, J. (2007). Parental leave for fathers? 
Gendered conceptions and practices in families with young children in Finland (Research Report No. 166). Vaajakoski: Stakes.

Lammi-Taskula, J., \& Takala, P. (2009). Negotiating tripartite compromises. In P. Moss \& S. Kamerman (Eds.), The politics of parental leave policies. Children, parenting, gender and the labour market (pp. 87-102). Bristol: Policy Press.

Mathieu, S. (2016). From the defamilialization to the "demotherization" of care work. Social Politics: International Studies in Gender, State \& Society, 23(4), 576-591.

Miettinen, A., \& Saarikallio-Torp, M. (2020). Isälle kiintiöidyn vanhempainvapaan käyttö ja sen taustatekijät [Take-up and background factors of father's quota]. Yhteiskuntapolitiikka, 4. Retrieved from https:// www.julkari.fi/handle/10024/140463

Miettinen, A., Salmi, M., Närvi, J., \& Lammi-Taskula, J. (2020). Finland. In A. Koslowski, S. Blum, I. Dobrotić, G. Kaufman and P. Moss (Eds.), International review of leave policies and related research 2020 (pp. 244-265). Hagen: Fakultät für Kultur- und Sozialwissen-schaften. Retrieved from https://www. leavenetwork.org/annual-review-reports/review2020

Oksala, I. (2017). EK:n malli perhevapaiden uudistamiseksi [Central organisation of employers' model for parental leave reform]. Helsinki: EK FI. Retrieved from https://ek.fi/wp-content/uploads/ Perhevapaat-EK-malli-28.2.2017_visu2.pdf

Picken, N., \& Janta, B. (2019). Leave policies and practice for non-traditional families. Luxembourg: Luxembourg Publications Office of the European Union.

SAK. (2016). Perhepalikat uusiksi. Perhevapaamalli [Rearrange the family blocks. Parental leave model]. Central Organisation of Finnish Trade Unions. Retrieved from https://www.sak.fi/aineistot/julkaisut/ perhepalikat-uusiksi-esitys

Salmi, M. (2017). Perhevapaakeskustelu etenee: Kotihoidon tuesta lastenhoidon järjestelmän uudistamiseen [The discussion on parental leave continues: From home care allowance to child care system reform]. In M. Salmi \& J. Närvi (Eds.), Perhevapaat, talouskriisi ja sukupuolten tasa-arvo [Parental leave, financial crisis and gender equality] (pp. 229-253). Helsinki: Terveyden ja hyvinvoinnin laitos.

Salmi, M., \& Lammi-Taskula, J. (2005). Leave policies and research in Finland. In F. Deven \& P. Moss (Eds.), Leave policies and research. Reviews and country notes (pp. 85-94). Brussels: CBGS.

Salmi, M., \& Lammi-Taskula, J. (2009). Country note: Finland. In P. Moss (Ed.), International review of leave policies and related research 2009. London: Department for Business Innovation \& Skills.

Salmi, M., \& Lammi-Taskula, J. (2010). 6+6+6-Malli vanhempainvapaan uudistamiseksi $[6+6+6$ Model for parental leave reform] (Päätösten tueksi 1/2010). Helsinki: Terveyden ja hyvinvoinnin laitos.
Salmi, M., \& Lammi-Taskula, J. (2015). Policy goals and obstacles for fathers' parental leave in Finland. In G. B Eydal \& T. Rostgaard (Eds.), Fatherhood in the Nordic welfare states-Comparing care policies and practice (pp. 303-324). Bristol: Polity Press.

Salmi, M., \& Närvi, J. (Eds.). (2017). Perhevapaat, talouskriisi ja sukupuolten tasa-arvo [Parental leave, financial crisis and gender equality] (Report 4/2017). Helsinki: Terveyden ja hyvinvoinnin laitos.

Salmi, M., Närvi, J., \& Lammi-Taskula, J. (2018). Finland: Country note. In S. Blum, A. Koslowski, A. Macht, \& P. Moss (Eds.), International review of leave policies and research 2018 (pp. 152-170). Hagen, Edinburg, Oxford and London: International Network On Leave Policies And Research. Retrieved from https://www.leavenetwork.org/fileadmin/user upload/k_leavenetwork/annual_reviews/2018/ Leave_Review_2018.pdf

Schreier, M., Stamann, C., Janssen, M., Dahl, T., \& Whittal, A. (2019). Qualitative content analysis: Conceptualizations and challenges in research practice-Introduction to the FQS special issue "Qualitative Content Analysis I." Forum: Qualitative Social Research, 20(3). Retrieved from https:// www.qualitative-research.net/index.php/fqs/ article/view/3393/4505

Sipilä, J., Repo, K., \& Rissanen, T. (Eds.). (2010). Cash-forchildcare: The consequences for caring mothers. Cheltenham: Edward Elgar.

Social Democratic Party. (2017). Vapaammat perhevapaat. SDP:n malli perhepolitiikan uudistamiseksi [More free parental leave. Social Democratic Party's model for parental leave reform]. Social Democratic Party. Retrieved from https://sdp.fi/fi/blog/sdpjulkaisi-perhevapaamallin

STM. (2005). Perhevapaista aiheutuvien kustannusten korvauksen kehittäminen Selvityshenkilön raportti. [Developing the compensation of parental leave costs. Rapporteur Report]. Ministry of Social Affairs and Health. Retrieved from https://julkaisut. valtioneuvosto.fi/bitstream/handle/10024/74028/ TRM200516.pdf?sequence $=1$

STM. (2011). Vanhempainvapaatyöryhmän muistio [Parental leave taskforce report] (Report 12:2011). Ministry of Social Affairs and Health. Retrieved from https://julkaisut.valtioneuvosto.fi/handle/10024/ 72167

STM. (2015a). Monimuotoisten perheiden perhevapaat [Parental leave in diverse families] (Report 45:2015). Ministry of Social Affairs and Health. Retrieved from http://julkaisut.valtioneuvosto.fi/bitstream/handle/ 10024/74725/RAP\%2045_2015.pdf

STM. (2015b). Miksi vanhempainpäivärahoja koskevia säännöksiä pitäisi uudistaa? [Why should the parental leave legislation be reformed?]. Ministry of Social Affairs and Health. Retrieved from https://stm.fi/-/miksi-vanhempainpaivarahojakoskevia-saannoksia-pitaisi-uudistaa-?_101_ 
INSTANCE_yr7QpNmIJmSj_languageld=en_US

STM. (2017a). Perhevapaauudistusta valmisteleva työryhmä [Task force preparing the family leave reform]. Ministry of Social Affairs and Health. Retrieved from https://stm.fi/hanke?tunnus= STM095:00/2017

STM. (2017b). Kaikki mallit [All models]. Ministry of Social Affairs and Health. Retrieved from https:// api.hankeikkuna.fi/asiakirjat/6bbf812c-3472-4467b870-aba692c6cb4b/202c0ed7-2c93-4f7e-8072c86508d5595a/MUISTIO_20180216070256.docx

STM. (2017c). Perhevapaamalleja taulukko [Table of family leave models]. Ministry of Social Affairs and Health. Retrieved from https://api.hankeikkuna. fi/asiakirjat/6bbf812c-3472-4467-b870-aba692c6 cb4b/94539652-2d9c-49b8-a4f6-860ad18fff2a/ MUISTIO_20180216071421.docx

STM. (2020). Perhevapaauudistus [Family leaves reform] Ministry of Social Affairs and Health. Retrieved from https://stm.fi/perhevapaauudistus

The Finnish Government. (1963). Sairausvakuutuslaki 364/1963 [The Act of Health Insurance 364/1963]. Helsinki: The Finnish Government. Retrieved from https://www.finlex.fi/fi/laki/alkup/1963/19630364

The Finnish Government. (1977). Laki sairausvakuutuslain muuttamisesta 1086/1977 [1086/1977 Amendment of the Act of Health Insurance]. Helsinki: The Finnish Government. Retrieved from https://finlex.fi/ fi/laki/alkup/1977/19771086

The Finnish Government. (1981). Laki sairausvakuutuslain muuttamisesta 471/1981 [471/1981 Amendment of the Act of Health Insurance]. Helsinki: The Finnish Government. Retrieved from https://finlex.fi/ fi/laki/alkup/1981/19810471

The Finnish Government. (1985). Laki sairausvakuutuslain muuttamisesta 32/1985 [32/1985 Amendment of the Act of Health Insurance]. Helsinki: The Finnish Government. Retrieved from https://finlex.fi/fi/laki/ alkup/1985/19850032

The Finnish Government. (1986a). Laki sairausvakuutuslain muuttamisesta 458/1986 [458/1986 Amendment of the Act of Health Insurance]. Helsinki: The Finnish Government. Retrieved from https://finlex.fi/ $\mathrm{fi} /$ laki/alkup/1986/19860458

The Finnish Government. (1986b). Laki sairausvakuutuslain muuttamisesta 1037/1986 [1037/1986 Amendment of the Act of Health Insurance]. Helsinki: The Finnish Government. Retrieved from https://finlex.fi/ fi/laki/alkup/1986/19861037

The Finnish Government. (1992). Laki sairausvakuutuslain muuttamisesta 1653/1992 [1653/1992 Amendment of the Act of Health Insurance]. Helsinki: The Finnish Government. Retrieved from https://finlex.fi/ fi/laki/alkup/1992/19921653

The Finnish Government. (1994). Laki sairausvakuutuslain muuttamisesta 1501/1994 [1501/1994 Amendment of the Act of Health Insurance]. Helsinki: The Finnish Government. Retrieved from https://finlex.fi/ fi/laki/alkup/1994/19941501

The Finnish Government. (1996). Laki sairausvakuutuslain muuttamisesta 1210/1996 [1210/1996 Amendment of the Act of Health Insurance]. Helsinki: The Finnish Government. Retrieved from https://finlex.fi/ fi/laki/alkup/1996/19961210

The Finnish Government. (2002a). Laki sairausvakuutuslain muuttamisesta 1075/2002 [1075/2002 Amendment of the Act of Health Insurance]. Helsinki: The Finnish Government. Retrieved from https://finlex.fi/ fi/laki/alkup/2002/20021075

The Finnish Government. (2002b). Hallituksen esitys laiksi sairausvakuutuslain muuttamisesta [Government proposal for the amendment of the Act of Health Insurance] (HE 147/2002). Helsinki: The Finnish Government. Retrieved from https://finlex.fi/ fi/esitykset/he/2002/20020147

The Finnish Government. (2006). Laki sairausvakuutuslain muuttamisesta 1342/2006 [1342/2006 Amendment of the Act of Health Insurance]. Helsinki: The Finnish Government. Retrieved from https://www. finlex.fi/fi/laki/alkup/2006/20061342

The Finnish Government. (2009). Hallituksen esitys laiksi sairausvakuutuslain 9 luvun 10a§:n muuttamisesta [Government proposal for the amendment of $\$ 10 a$ in chapter 9 of the Act of Health Insurance] (HE 131/2009). Helsinki: The Finnish Government. Retrieved from https://www.finlex.fi/fi/ esitykset/he/2009/20090131

The Finnish Government. (2010). Hallituksen esitys eduskunnalle laiksi sairausvakuutuslain 9§ muuttamiseksi [Government proposal for the amendment of $\S 9$ of the Act of Health Insurance] (HE 15/2010 vp). Helsinki: The Finnish Government. Retrieved from https://www.eduskunta.fi/Fl/vaski/ HallituksenEsitys/Documents/he_15+2010.pdf

The Finnish Government. (2016). Hallituksen esitys eduskunnalle laeiksi sairausvakuutuslain ja elatustukilain $6 a \S$ ja $8 \S$ muuttamisesta sekä eräiksi muiksi avioliittolain muutokseen liittyviksi laeiksi [Government proposal for the amendment of the Act of Health Insurance and the Act of Alimony to a Child, and certain other amendments related to the amendment of the Marriage Act] (HE 232/2016 vp). Helsinki: The Finnish Government. Retrieved from https://finlex.fi/ fi/esitykset/he/2016/20160232

The Finnish Government. (2018). Hallituksen esitys laiksi sairausvakuutuslain muuttamisesta [Government proposal for the amendment of the Act of Health Insurance] (HE 206/2018 vp). Helsinki: The Finnish Government. Retrieved from https://www. eduskunta.fi/Fl/vaski/HallituksenEsitys/Sivut/ HE_206+2018.aspx

Työministeriö. (2005). Perhevapaasäännösten toimivuus: Perhevapaasäännösten toimivuutta arvioivan työryhmän raportti [Report of taskforce on functionality of parental leave legislation] (Ministry of Employment Report No. 358:2005). Helsinki: Työministeriö. 
Vihreät. (2016). Joustoa ja valinnanvapautta perheille. Vihreä perhepolitiikka [Flexibility and freedom of choice for families. Green family policy]. Vihreät. Retrieved from https://www.vihreat.fi/ajankohtaista joustoa-ja-valinnanvapautta-perheille
Wong, E., Jou, J., Raub, A., \& Heymann, S. (2019). Comparing the availability of paid parental leave for same-sex and different-sex couples in 34 OECD countries. Journal of Social Policy, 49(3). https://doi.org/ $10.1017 /$ S0047279419000643

\section{About the Authors}

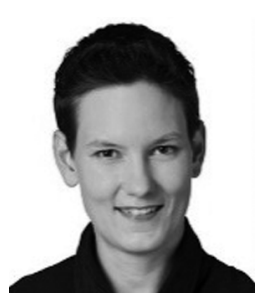

Anna Moring (PhD) is Leading Expert at the Network of Family Diversity. Her research interests include kinship and family studies, LGBTIQ+ families and family law. The main aim of her work is to provide legislators with the information they need about diverse families and family situations. She has edited books about gender equality in politics as well as close relations in an LGBTIQ+ context and has been a member of several governmental committees and workgroups in matters related to family law.

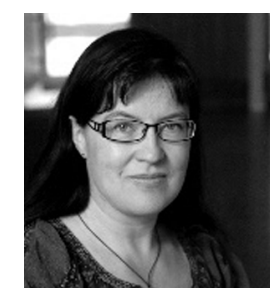

Johanna Lammi-Taskula (PhD) is a Sociologist and Research Manager at the Finnish Institute for Health and Welfare (THL). Her main research interests include the reconciliation of work and family life, parental leave policies, the well-being of children and families, and gender equality. She has authored or co-authored several publications on these themes in Finnish, English and Swedish and worked in many governmental committees and national working groups in Finland as an expert on family policy and gender equality. She is a member of the International Network on Leave Policies \& Research. 